\title{
Boekbespreking
}

\section{Huub Dijstelbloem - Het huis van Argus, Boom uitgevers 2016}

\author{
Een alternatieve recensie - Argus en de kunst van het kijken
}

\begin{abstract}
Jeroen Postma, Kor Grit en Annemiek Stoopendaal*
\end{abstract}
Vorig jaar verscheen 'Het huis van Argus. De makende blik in de democratie' van auteur Huub Dijstelbloem. ${ }^{1}$ Het boek bevat belangrijke aangrijpingspunten voor het doordenken van ontwikkelingen in het toezicht op de zorg en andere sectoren. Met name ten aanzien van het betrekken van burgers in het toezicht, een richting die verschillende toezichthouders exploreren. Wij vroegen Dijstelbloem daarom in een bijeenkomst in onze vakgroep Health Care Governance met ons van gedachten te misselen over het boek. Ter voorbereiding schreef Jeroen Postma een review in de vorm van een verhaal. Deze recensie is een synthese van dat verhaal en de discussie over toezicht tijdens de bijeenkomst. Wij hebben het thema 'verbeelding' uit het boek gebruikt om Argus, genoemd naar de Griekse reus die honderd ogen bezat waarvan er nooit meer dan twee tegelijk rustten, tot leven te mekken en tevens kritisch te beschoumen.

Argus schenkt een kop koffie in en kijkt peinzend uit het raam. Het bestaan als zelfstandige is even wennen. 'Uw burger-detective: voor een wakende blik in de samenleving', staat op haar visitekaartje. Voordat ze als zzp'er

* Dr. J.P. Postma is universitair docent/wetenschappelijk onderzoeker aan het Instituut Beleid en Management Gezondheidszorg van de Erasmus Universiteit Rotterdam. Dr. K.J. Grit is universitair docent/wetenschappelijk onderzoeker aan het Instituut Beleid en Management Gezondheidszorg van de Erasmus Universiteit Rotterdam. Dr. A.M.V. Stoopendaal is universitair docent/wetenschappelijk onderzoeker aan het Instituut Beleid en Management Gezondheidszorg van de Erasmus Universiteit Rotterdam.

1. Prof. dr. H.O. Dijstelbloem is hoogleraar filosofie en politiek aan de Universiteit van Amsterdam. Tevens is hij als onderzoeker verbonden aan de Wetenschappelijke Raad voor het Regeringsbeleid (WRR) en medeoprichter van het Center for Public Imagination. begon, had ze lang nagedacht over het functioneren van de samenleving, met name over de verhouding tussen staat en burgers. Argus was ervan overtuigd geraakt dat de samenleving niet alleen gebaat is bij burgers die meedoen en meepraten, maar ook bij burgers die afstand houden, waakzaam zijn, kijken en controleren. Dat is des te belangrijker wanneer de traditionele staat door technologische ontwikkelingen, privatisering, verzelfstandiging en samenwerking met het bedrijfsleven transformeert in een metastaat die niet altijd materieel aanwezig is, maar zijn oog richt op veel meer plaatsen dan voorheen. Plaatsen waar burgers en hun organisaties worden bekeken, terwijl ze zelf steeds minder mogelijkheden hebben om vooraf invloed uit te oefenen op waar de metastaat naar kijkt en wat deze met die informatie doet. Terugkijken wordt dan een belangrijke vorm van actief burgerschap.

Argus had lang geaarzeld of ze zichzelf 'detective' wilde noemen. De titel riep associaties op met Sherlock Holmes en miss Marple: geniale geesten die op afstand staan van de werkelijkheid en complexe zaken oplossen door empirische waarneming, het stellen en toetsen van hypothesen en het vormen van theorieën. Argus ziet zichzelf minder als objectieve observator en meer als deelnemer: betrokken bij zaken, affectief, hoopvol, soms ook wantrouwig of manipulatief. Niet met een alziend oog maar met wisselende perspectieven. Zien en gezien worden zijn volgens Argus geen onschuldige bezigheden, maar vormen een esthetische strijd, het uitoefenen van macht en tegenmacht. Wat gezien wordt, is belangrijk en interessant en kan worden bediscussieerd in de politieke en maatschappelijke arena. Wat onzichtbaar bliift, wordt minder waardevol en onttrekt zich aan con- 
trole, verantwoording en debat. Daarom vond Argus de term 'detective' uiteindelijk wel passend. De detective houdt zich bezig met reconstructie: het zichtbaar maken van het onzichtbare, het terugkijken naar wat is gebeurd en het vooruit kijken naar wat beter kan. Reconstructie is geen koude boekhoudkundige exercitie, maar vraagt om betrokkenheid, het reflectieve vermogen om perspectief te ontwikkelen en de durf om informatie te vinden en te ontsluiten. Reconstructie vereist verbeelding, waarbij de detective voortdurend schakelt tussen kijken en doen, deelnemen en observeren, perspectief kiezen en vuile handen maken.

Kijk en bekeken worden zijn niet alleen belangrijke thema's in de bestuurskunde en de politicologie, maar ook in de literatuur. Met de kop koffie in haar hand loopt Argus naar de boekenkast, waar haar blik valt op Het Proces van Franz Kafka, uit 1915. De hoofdpersoon wordt op een dag van zijn bed gelicht door de overheid, zonder dat hij weet waarvoor en zonder dat anderen hem dat gedurende een gekmakende rondgang door de bureaucratie kunnen vertellen. Alles weten ze van hem, maar het enige dat hij ziet als hij terugkijkt, zijn onbegrijpelijke formulieren en emotieloze beambten. Eenzelfde onmachtig gevoel kreeg Argus bij het lezen van het boek dat ernaast op de plank staat, 1984 van George Orwell. Een allesdoordringende staat die bepaalt hoe we werken, leven en zelfs denken. Met als belangrijkste machtsmiddel de mogelijkheid om voortdurend bekeken te worden: door je buren die zomaar als spionnen voor de staat kunnen werken of vanuit de grote schermen die iedereen in huis heeft hangen. Ook hier weer is terugkijken onmogelijk. Dat verandert in The Circle uit 2013, van Dave Eggers, een roman die Argus misschien nog wel het meest verontrustte. The Circle is een bedrijf dat zich tot doel heeft gesteld alle informatie die bestaat voor iedereen in real time vindbaar en doorzoekbaar te maken. The Circle heeft onder andere een camera ontwikkeld die mensen om kunnen hangen en waarmee ze hun hele leven live kunnen streamen. Het verontrustende is dat The Circle mensen niet dwingt met de traditionele machtsmiddelen van de staat, maar dat ze zichzelf sturen en als lemmingen achter de technologie aanlopen met de leus: 'Secrets are lies, Sharing is caring, Privacy is theft'. Wie nu nog onzichtbaar is, is bij voorbaat verdacht en verwordt tot een paria van de samenleving.

Argus schrikt op uit haar overpeinzingen door het geluid van de deurbel. Ze doet open en kijkt in de bezorgde gezichten van haar vrienden Hydra, Metis en Apate. 'Argus, we moeten praten', zegt Hydra terwijl hij naar binnen stapt. 'We vinden het goed dat je voor jezelf bent begonnen, maar we zijn bang dat je bedrijfsfilosofie niet helemaal klopt. Je richt je namelijk op de staat, bedrijven en burgers, maar mist daarmee de toezichthouders. En dat terwijl hun kerntaak bestaat uit het kijken naar de samenleving. Hier ligt een kans voor je onderneming: over toezichthouders bestaat door een reeks van incidenten veel maatschappelijke onvrede. Kan een relatief kleine groep van inspecteurs wel toezien op talloze publieke en private dienstverleners en producenten? Vanuit wiens perspectief en wiens belang wordt er toegezien: vanuit de staat, private organisaties of de burger? Hebben toezichthouders wel oog voor het geheel, wanneer het hele systeem de dader lijkt? Want wie vermoordde de handen aan het bed in de ouderenzorg of de veiligheid bij de Groningse gaswinning? De wakende blik van de staat kan wel wat hulp gebruiken en tegelijkertijd hebben toezichthouders een wakende blik nodig die op hen toeziet. Kijk Argus, je hebt een veel breder, drievoudig takenpakket als burger-detective. Je moet kijken naar: (1) de actoren die reguleren, (2) de actoren die toezicht houden en (3) de actoren die object van toezicht zijn.' Hydra lacht even en concludeert: 'Je zult als burger-detective een veelkoppig monster moeten zijn. Ik denk niet dat je dat in je eentje kunt.'

Nog voordat Argus dit alles heeft verwerkt, neemt Metis het woord. 'Weet je Argus, je hebt gelijk dat we voortdurend worden begluurd door de overheid en bedrijven: als we achter onze laptop zitten, onze mobiele telefoon gebruiken of gewoon als we op straat lopen. Maar dit resulteert niet in één helder beeld; het resulteert in ontelbare fragmenten die alleen met zeer veel moeite tot een betekenisvol mozaiek kunnen worden gemaakt. Informatie over ons is in vele verschillende databases opgeslagen, beheerd door een veelheid aan nationale en internationale bedrijven en overheidsdiensten. Het koppelen van gegevens is technisch erg ingewikkeld, wat iedereen kan beamen die wel eens een ICT-project in een organisatie heeft meegemaakt. Daarnaast is er gelukkig ook nog allerlei regelgeving die onze privacy beschermt. Fragmentatie van informatie en de complexiteit van interpretatie is echter ook een probleem voor toezichthouders bij het beschermen van het publieke belang. Hoe kunnen zij nu echt weten wanneer de kwaliteit en veiligheid van producten en diensten in gevaar is? Hoe kan het dat bedrijven die net een positieve beoordeling hebben gehad, toch te maken kunnen krijgen met een groot incident?' Metis denkt even na en vervolgt: 'Betekenisvol zien doet een groot beroep op de mijsheid van de betrokken actoren, waarbij het midden moet worden gevonden tussen laissez faire en een doorgeschoten veiligheidscultuur die individuele rechten geweld aandoet en waarin angst innovatie onmogelijk maakt.'

Nadat ze wat te drinken voor haar vrienden heeft ingeschonken richt Argus haar blik op Apate. Die zucht even en zegt: 'Ik heb moeite met je gebruik van het begrip verbeelding. Je kent dat twee betekenissen toe. De eerste is het creatieve proces van dromen, voorstellen, inbeelden: "stel je voor...". De tweede betekenis is het visueel maken van wat belangrijk en interessant is, het gebruik van beelden. Verbeelding kan een krachtig instrument zijn in het toezicht, maar kent ook grote risico's. De lat voor productieve verbeelding ligt hoog: het vraagt om creatief en abstract denken, reflectie en zelfbeheersing, het kunnen filteren, selecteren en verbinden van informatie en het creatieve vermogen tot visualiseren. Hoeveel burgers en toezichthouders zijn daar nu echt toe in staat? Ongelimiteerde verbeelding daarentegen leidt al snel tot 'alternative facts', complottheorieën, fantasie, aantijgingen en digitale schandpalen. Hoe 
voorkom je dat verbeelding verwordt tot spektakel, waarin problemen worden opgeblazen en feiten er niet meer toe doen? Waarin langdurige reputatieschade voortdurend op de loer ligt door zwarte lijsten en de aanklagende functie van het internet? Negatieve krachten drijven vaak op dramatiek en gemanipuleerde beelden die een gevaar kunnen zijn voor de democratische samenleving. Juist in het toezicht zijn waarden als zorgvuldigheid, feitelijkheid, proportionaliteit en rechtszekerheid daarom van groot belang, waarden die in de verbeelde wereld vooral hinderlijk zijn.' Apate kijkt Argus indringend aan. 'Pas op, Argus: verbeelding kan gemakkelijk ontaarden in misleiding.'

Nadat haar vrienden zijn vertrokken blijft Argus in enige verwarring, maar ook met een hoofd vol nieuwe ideeën achter. De reflectie van Hydra had haar geleerd dat kruisende blikken een gegeven zijn in een samenleving waarin technologie en (sociale) media surveillance van en door vele ogen mogelijk maakt. De signalerende en soms aanklagende rol van burgers verdient daarom serieuze aandacht van inspecteurs en toezichthouders. Dit biedt ook een opening om burgers een productieve rol te geven in het toezicht, bijvoorbeeld door ze in te zetten als 'mystery guest' of burger-inspecteur. De burger-inspecteur is zowel in staat om mee te kijken naar de onder toezicht staande als om te reflecteren op het werk van de professionele inspecteur. De wijze woorden van Metis deden Argus inzien dat interpretatie van informatie een delicate aangelegenheid is in de toezichtpraktijk. Een goede reconstructie van gebeurtenissen is een kunst op zich, waarbij het zaak is te zoeken naar een gedeelde weergave van feiten en tegelijkertijd ruimte te bieden aan verschillen in de interpretatie ervan. Juist in een samenleving met vele ogen, alle kijkend vanuit een ander perspectief, is het voor inspecteurs en toezichthouders essentieel om aandacht te hebben voor pluriformiteit. Van de kritiek van Apate ten slotte leerde Argus dat verbeelding en misleiding dicht bij elkaar kunnen liggen. Toezichthouders moeten zich voortdurend bewust zijn van de consequenties van hun verbeelding: wat eenmaal zichtbaar is gemaakt, wordt nooit meer onzichtbaar. En het verbeelde kan op talloze manieren worden gemanipuleerd, met grote en langdurige negatieve gevolgen voor onder toezicht gestelden. Deze schaduwzijde van verbeelding vraagt om toezichthouders die de informatie van de vele wakende ogen zorgvuldig afwegen en kritisch weerwoord kunnen bieden aan een voortdurende roep om steeds meer transparantie en bestraffing. Oude waarden van toezicht vragen om herijking in een nieuwe, verbeelde wereld. 'Ik heb een goed beroep gekozen', zegt Argus hardop tegen zichzelf, 'er is nog een wereld te winnen'. 